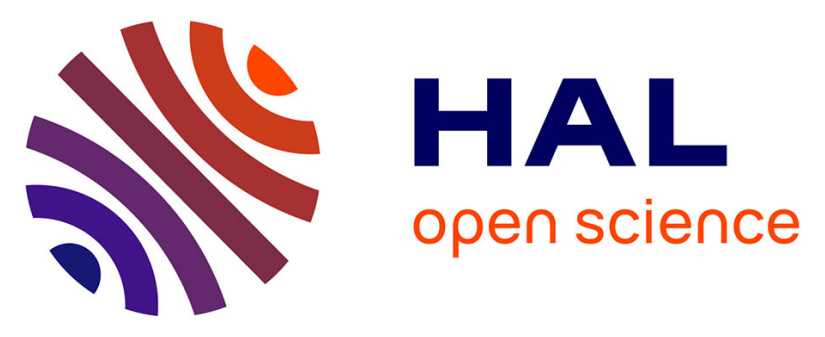

\title{
Landscaping compromises for land degradation neutrality: The case of soil erosion in a Mediterranean agricultural landscape
}

Anna Smetanova, Stéphane Follain, Mélodie David, Rossano Ciampalini, Damien Raclot, Armand Crabit, Yves Le Bissonnais

\section{To cite this version:}

Anna Smetanova, Stéphane Follain, Mélodie David, Rossano Ciampalini, Damien Raclot, et al.. Landscaping compromises for land degradation neutrality: The case of soil erosion in a Mediterranean agricultural landscape. Journal of Environmental Management, 2019, 235, pp.282-292. 10.1016/j.jenvman.2019.01.063 . hal-02067100

\section{HAL Id: hal-02067100 \\ https://institut-agro-dijon.hal.science/hal-02067100}

Submitted on 21 Oct 2021

HAL is a multi-disciplinary open access archive for the deposit and dissemination of scientific research documents, whether they are published or not. The documents may come from teaching and research institutions in France or abroad, or from public or private research centers.
L'archive ouverte pluridisciplinaire HAL, est destinée au dépôt et à la diffusion de documents scientifiques de niveau recherche, publiés ou non, émanant des établissements d'enseignement et de recherche français ou étrangers, des laboratoires publics ou privés.

\section{(ㄷ)(1) $\$$}

Distributed under a Creative Commons Attribution - NonCommerciall 4.0 International 
Version of Record: https://www.sciencedirect.com/science/article/pii/S0301479719300696

Manuscript_6e5855dd4c90e41ced12b0f2596eba3e

Short Title: Target for catchment land degradation neutral management in Mediterranean

Long title: Landscaping compromises for land degradation neutrality: the case of soil erosion in a Mediterranean agricultural landscape

Anna Smetanováa,b, Stéphane Follainc ${ }^{c}$, Mélodie David ${ }^{b, d}$, Rossano Ciampalini ${ }^{b}$, Damien Raclot ${ }^{b, e}$, Armand Crabit ${ }^{b}$, Yves Le Bissonnais ${ }^{b}$

${ }^{a}$ Research Group Ecohydrology and Landscape Evaluation, Ernst-Reuter PLatz 1, DE-10623, Berlin, Germany

b LISAH, INRA, IRD, Montpellier SupAgro, Univ Montpellier, FR-34060, Montpellier, France

${ }^{c}$ Agroécologie, AgroSup Dijon, INRA, Univ. Bourgogne, Univ. Bourgogne Franche-Comté, F-21000 Dijon, France

d GEODE UMR 5602, Maison de la Recherche, FR-31500, Toulouse, France

e Institut Agronomique et Vétérinaire Hassan II, Dept. of Natural Resources and Environment, PO.

Box. 6608, Madinat Al Irfane, Rabat, Morocco

corresponding author:

Anna Smetanová, Department of Ecohydrology and Landscape Evaluation, TU Berlin, Ernst-Reuter

Platz 1, DE-10623, Berlin, Germany, anna.smetanova@gmail.com, Tel: +49 3031473534 


\section{Abstract}

2 Soil erosion is the primary process driving land degradation. Using multiple scales of

3 management to minimize soil erosion is crucial to achieve land degradation neutrality targets

4 within the Sustainable Development Goals agenda. Land management (LM) influences both on-

5 site and off-site erosion on the event-scale and over the long-term. However, each LM differs in

6 effectiveness depending on the temporal scale considered. In order to understand how LM

7 effects internal and external catchment dynamics, we apply LandSoil, a physically based

8 landscape evolution model, to evaluate 7 LM scenarios over long- (30 years) and short-terms

9 (event scale). LM scenarios included changes in land use and/or landscape structure. Under current LM, mean surface soil erosion was $\sim 0.69 \pm 39 \cdot 10^{-3} \mathrm{~m}$ over 30 years. In contrast, a

11 single extreme event (435 mm/24h) in January resulted in $\sim 0.62 \pm 3 \cdot 10^{-3} \mathrm{~m}$ loss and $\sim 0.04 \pm$

$122 \cdot 10^{-3} \mathrm{~m}$ if it occurred in October. Heterogeneous patterns of erosion and deposition developed

13 after 30 years, whereas extreme events dominantly showed soil loss and high catchment connectivity. Effectiveness of LM in erosion mitigation and sediment trapping differed according to temporal and spatial scales for each scenario. We concluded that multiple temporal and spatial scales must be incorporated in order to adaptively manage land degradation and meet neutrality targets.

Key words:

Land degradation, Degradation neutrality, Soil erosion, Landscaping, Mitigation strategy

1. Introduction

Land degradation neutrality targets of the Sustainable Development Goals (SDG 15.3) contain time-specific measures to avoid, reduce and reverse land degradation at both national and subnational levels (The Global Mechanism of UNCCD, 2016). Soil erosion by water is a major

27 land degradation process (Orr et al, 2017). Therefore, land management seeking to minimize soil erosion is crucial for maintaining food and water security, climate regulation, soil ecosystem services (Dominati et al., 2010; Koch et al., 2013; Lal, 2004; McBratney et al., 2014; 
Montanarella et al., 2016; and achieving of multiple SDGs (Keesstra et al., 2016; Orr et al., 2017).

33 It is expected, that soil erosion and suspended sediment yield in rivers will increase beginning in

34 the mid-21st century due to climate change (Raclot et al., 2018; Routschek et al., 2014a, 2014b, Bussi et al., 2016; Rodríguez-Blanco et al., 2016). The majority of soil loss occurs during highmagnitude events of low frequency/recurrence, especially in Mediterranean environments where 3-10 of the largest daily events can account for over 50\% of total soil loss (González-Hidalogo et al., 2007, 2010). Due to climate change, the frequency of high-magnitude rainfall events increases (e.g., Serpa et al., 2015). Therefore, considering seasonal patterns of soil loss (Smetanová et al., 2018) alongside water and sediment connectivity, and evaluating economic effects of on- and off-site effects of land management are all essential for preventing land degradation (García-Ruiz et al, 2017; Raclot et al., 2018).

Land use influences both soil erosion (sediment production) and sediment connectivity, while landscape structure can influence sediment transport and connectivity (Ciampalini et al., 2012; Coulthard \& Van De Wiel, 2017; David et al, 2014; Follain et al., 2006; Fryirs, 2013). Modelling studies shown, that proper management can reduce the future effects of climate change on midand long-term soil erosion rates (Parroissien et al.2015; Rodriguez-Lloveras et al., 2016; Routschek et al., 2014a, 2014b). Modelling approaches successfully tested the effects of crop allocation, sediment trapping, and ditch optimisation techniques under mean or extreme rainfall events (David et al, 2014; Furlan et al., 2012; Gumiere et al., 2014; Levavasseur et al, 2016; Mullan et al., 2016; Nunes et al., 2013; Ronfort et al., 2011).

However, in order to meet land degradation neutrality targets, it is crucial to focus land management simultaneously on the relevant spatial and temporal scales for erosional processes (Larson et al., 1997; Stroosnijder, 2005) and stakeholders' scales of practice (Smetanová, et al, 2018). This requires providing of multi-foci, multi-scale solution. For example, a management reducing sheet and gully erosion during high-magnitude events of low 
frequency/recurrence, and in long-term. Simultaneously, an effective management should reflect differing priorities of stakeholders operating in the same region. For example, the spatial scale of interests and mind-sets of a vineyards farmer and watershed manager might likely differ between understanding internal catchment dynamics on individual field scales (farmer) versus external catchment dynamics (e.g., sediment export to reservoirs). Furthermore, farmers establishing vineyards are interested in soil productivity over timescales that plants achieve highest productivity (10-30 years), while watershed managers might focus on reducing or preventing flash floods (single events). Understanding how land management effects on soil erosion contrast on temporal and spatial scales can help define targets for land management decisions aimed at reducing land degradation.

69

The objective of this study is to compare the internal and external catchment soil erosion dynamics for different land management scenarios over short-term (event scale) and long-term (30 years) scales, in order to answer the question: "Should management strategies for land degradation be tailored for specific spatial and temporal scales to achieve land degradation neutral management?"

2. Materials and Methods

2.1 Study site

The Roujan catchment $\left(0.91 \mathrm{~km}^{2}\right)$, located in south France $\left(43^{\circ} 30^{\prime} \mathrm{N}, 3^{\circ} 19^{\prime} \mathrm{E}\right)$ has been monitored for rainfall in the three meteorological stations equipped with tipping bucket rain gauges, and for continuous runoff and sediment concentration at parcel, mid- and whole catchment since 1992. It was described comprehensively by David et al. (2014). It belongs to a sub-humid Mediterranean climate (Peel et al., 2017) with mean annual rainfall $634 \mathrm{~mm}$ and a dry summer period, with maximum runoff and sediment yield from October to February. Elevation ranges 50m and slopes are 2-20\% (David et al., 2014). Miocene marine and lacustrine sedimentary rocks with calcaric Regosols and Calcisols cover most of the catchment.

87 Land use is dominated by vineyards (62\%) followed by cereal and alfalfa production, and 
scrubland (Guix-Hébrard et al., 2007). Chemical weeding in vineyards is performed using herbicide application alongside mechanical weeding by shallow $(0.05-0.10 \mathrm{~m})$ tillage with a duck foot cultivator in spring and autumn (Biarnès and Colin, 2006; Coulouma et al., 2006). Wheat and barley are rotated in the fields with annual crops. Fields are treated biannually in the post-harvest period (summer-autumn) with a disc-and-chisel plough down to depths of 7 to 12 $\mathrm{cm}$. Landscape structure is characterised by 140 fields $(0.6 \pm 0.5 \mathrm{ha})$ with grass, bare soil or vegetated compacted soil strips along field borders, and an 11-km network of ditches (David et al. 2014). Current land use and landscape structures represent baseline land use scenario 96 (Figure 1).

97

\subsection{LandSoil model}

LandSoil model was previously developed and calibrated in Roujan catchment (Ciampalini et al.

100 2012), and since then applied in variety of environments (e.g., Ciampalini et al.2011; Chartin et

101 al, 2011; Lacoste et al., 2016). LandSoil is a spatial raster-based model for simulating water and

102 tillage soil erosion as well as evolution of topography at plot to catchment scale. After modelling each event, LandSoil recalculates the elevation raster. Soil surface properties control water

104 infiltration, runoff, and sediment concentration for each grid-cell and rainfall event (David et al., 2014; Leonard and Andrieux, 1998). Runoff in each grid cell is combination of input from upstream/upslope cells and runoff generated within the cell. Runoff flows in the flow line direction, or, if flow lines are interrupted, along liner landscape elements (roads, ditches, field

108 boundaries, and tillage rows). The model uses a modified single-flow runoff model (Jenson and

109 Domingue, 1988; Souchère et al., 1998) under eight possible flow directions. Both contour and

110 downslope tillage were modelled in different fields with tillage transport coefficients spanning

111 111-139 $\mathrm{kg} \mathrm{m}^{-1}$ (David et al., 2014).

\section{2.4. Numerical experiment scheme}

115 We considered two temporal dynamics (Figure 2):

116 (i) Long-term - 30 years. This period refers to long-term erosion rates over the timescale 
that a new vineyard will reach peak productivity.

(ii) Single extreme rainfall event - maximum measured daily rainfall event. Events were modelled for January and October in order to consider variability in soil surface properties (David et al., 2014) that arise during periods when large erosion events

We considered two spatial dynamics:

(i) Internal catchment dynamics - represented by fine spatial resolution modelling (1-meter grid) to simulate erosion and deposition patterns over the entire catchment. It related to

We applied seven predictive land use scenarios that combine narrative and modelling methods developed by David et al. (2014). Three narratives were (i) stationary production (B - "baseline", corresponding to current land mangement), (ii) more intensive production (I - "intensified"), and (iii) less intensive production (E - "extensified") than stationary production. These narratives

133 were transformed into seven scenarios (BLUS, ILU; ILS; ILUS; ELU, ELS, ELUS) by modifying

134 the baseline land use and / or landscape structure by allocation rules for of land use (LU) and

135 landscape structure (LS) as described in Figure 3.

2.5. Model inputs

\section{Elevation and soil surface topography}

140 LIDAR-based digital elevation model derived at 2-m resolution (David et al., 2014) represented

141 initial input topography for all scenarios. Elevation was recalculated after every/each event by

142 subtracting the depth of eroded soil or adding the height of deposited sediment in each raster

143 cell. Soil erosion rates and sediment export (in $\mathrm{Mg} \cdot \mathrm{km}^{-2}$, where $1 \mathrm{Mg} \cdot \mathrm{km}^{-2}$ corresponds to 0.01

144 tonnes per hectare) at the catchment outlet were recalculated at the end of each simulation

145 period based on equations provided by David et al. (2014). 


\section{Rainfall dataset}

148 Long-term rainfall series were based on 10-years extension of empirical rainfall event

149 measurements in the Roujan catchment between 1992-2012 (David et al., 2014; Figure 4). The

150 total rainfall depth $(\mathrm{mm})$, maximum intensity over $6 \mathrm{~min}(\mathrm{~mm} \mathrm{~h}-1)$ and rainfall duration $(\mathrm{h})$ were

151 considered for each event, separated by at least a 6-hour dry period.

152 An event with return period $>100$ years was represented by extreme event measured in

153 Perpignan (120km from Roujan) on 26 October, 1915 (Cosadney and Robison, 2000; Meteo

154 France, 2018). Rainfall depth was $435 \mathrm{~mm}$ over 24 hours, but no measurement of rainfall

155 intensity was available. Rainfall intensity was estimated using the Montana law, with results

156 suggest that the Montana coefficient value exceeded the maximum intensity class for the

157 LandSoil model. Therefore, the maximum rainfall intensity class $\left(>40 \mathrm{~mm} \mathrm{~h}^{-1}\right)$ was applied

158 based on calibration from Ciampalini et al. (2012). Model parameters and soil conditions are

159 described in additional detail by David et al. (2014).

160

\section{Tillage Dataset}

162 Modelled tillage events occurred in fields with annual crops and in vineyards with mechanical

163 weeding. We simulated tillage twice a year in April or May and October. The exact day of a

164 tillage simulation was determined by cumulative rainfall depth $(40 \mathrm{~mm})$ since the last tillage 165 event.

166

167 3. Results

168 3.1 Temporal dynamics: Long-term vs. extreme event soil erosion

170 Under current land use and landscape structure conditions (BLUS), mean soil loss was $0.69 \pm$ $17138.97 \cdot 10^{-3} \mathrm{~m}$ across the catchment over the 30-year simulation period (Table 1). Mean soil loss 172 here is the mean of all raster-cell values after 30 years of simulation. Each raster-cell value 173 represented cumulative elevation change after 30 years of simulation. Soil export at the outlet

174 (i.e., external catchment dynamics) under BLUS scenario was $9.02 \cdot 10^{-2} \mathrm{Mg} \cdot \mathrm{km}^{-2}$. Soil export at 
catchment outlet varied from 4.74 (ELUS) to $119.20 \cdot 10^{-2}{\mathrm{Mg} \cdot \mathrm{km}^{-2}}$ (ILUS).

176 Erosional responses to single extreme rainfall events differed from long-term (30 years)

177 cumulative soil loss and were different for January and October. Mean soil loss in single

178 extreme rainfall event was $0.60 \pm 2.72 \cdot 10^{-3} \mathrm{~m}$ in January, and $0.00 \pm 1.55 \cdot 10^{-3} \mathrm{~m}$ in October

179 under BLUS scenario. Sediment export (external dynamics) was $16.4 x$ higher in January than in

180 October. Similar patterns were observed in other scenarios, where mean soil loss for extreme

181 events were 1.3x (ILU) to 20x (ELS) higher in January relative to October.

182 Comparing mean soil loss of long-term and extreme events (Table 1) under BLUS scenario

183 showed that $8.3 \pm 14$-times more soil was eroded after thirty years than by a single extreme

184 event in January.

185 Sediment exported by a single event in January or October is only reached as the cumulative

186 effect of many erosion events under normal rainfall conditions. This comparison could be called

187 'equal erosion delivery', which refers to the duration required for continuous "normal" erosion to

188 match the quantity of sediment delivered by an extreme event. In BLUS, sediment exported in

189 January was reached after $\sim 27$ years, while sediment exported during October was matched

190 after $\sim 2$ years. Sediment exported in all January extreme events was reached in $\sim 21-26$ years

191 under extensified land use scenarios, but dropped drastically to 2-4 years if October extreme

192 events were considered. Under ILU and ILUS, soil loss by both extreme events were more

193 similar than by all remaining scenarios. Under long-term rainfall conditions, an equivalent

194 amount of sediment export was reached in 6-7 years.

195

1963.2 Internal catchment dynamics

198 Long-term rainfall conditions under current land use and landscape structure (BLUS) led to soil

199 redistribution within the catchment (Figure 5B). Soil loss ranged from 0.01 to $0.3 \mathrm{~m}$ in vineyards 200 with chemical weeding, with less than $0.01 \mathrm{~m}$ loss in scrubland and no tillage annual crop fields.

201 In vineyards with mechanical weeding and in fields with tilled annual crops, erosion ranged from

2020.01 to $0.3 \mathrm{~m}$ and deposition $>0.01 \mathrm{~m}$ occurred. Rills created in parcels with no tillage and

203 scrubland were infilled by shallow deposition $(<0.01 \mathrm{~m})$. Zero net erosion or deposition $\left(<10^{-12} \mathrm{~m}\right)$ 
was observed on or along linear landscape structures (e.g., roads, field borders).

206 In contrast to previous results, during an extreme event in January (Figure 5C), net soil loss was

2070.01 to $0.3 \mathrm{~m}$ in all land uses excluding scrubland, where a series of long rills with depths <

$2080.01 \mathrm{~m}$, were created. Rills deeper than $0.3 \mathrm{~m}$ were formed along some recent and/or historical

209 linear landscape structures. Deposition $>0.1 \mathrm{~m}$ only took place on some of the vegetated strips.

210 During an extreme event in October, mean soil loss was lower than that from extreme events in

211 January (Table 1). Furthermore, the rill network within scrubland and along field borders was

212 less dense and generally, shorter rills infilled with less than $0.01 \mathrm{~m}$ sediment (Figure 5D). "Equal

213 erosion delivery" duration was 27-years for an extreme event in January. However, soil

214 redistribution patterns were completely different (Figure 5E). Sediment exported during an

215 extreme rainfall event in October was reached after $\sim 2$ years of long-term rainfall conditions

216 (Figure 5F), but contrary to extreme rainfall in October (Figure 5D) nearly zero erosion or

217 deposition occurred within most of the parcels under normal rainfall conditions.

219 For other scenarios, the relation between long-term and extreme event internal catchment

220 dynamics was similar to those in BLUS (Supplementary Info 1). Normal rainfall simulations led

221 to heterogeneous soil redistribution patterns with areas of both erosion and deposition after 30

222 years, while nearly zero net soil erosion over the majority of the catchment during extreme

223 events.

224 Differences in internal catchment dynamics for each temporal scale are shown using an example of upper (terraced) slopes divided to two parcels (Figure 6). The upper parcel was

226 divided to one (ILS) or more (BLUS, ELS) fields with mechanical weeding. Chemical weeding

227 was applied in ILU and ILUS scenarios, while scrubland covered the parcel in ELU and ELUS

228 (Figure 6A). The lower parcel was covered by scrubland in all scenarios, but the field border

229 cover varied (Figure 6A). Under scenarios of intensified land use (ILU and ILUS), 0.01-0.3 m of

230 soil was removed from surface in vineyards with mechanical weeding. Furthermore, deep rills

231 (0.01-0.3 m) in scrublands were infilled with transported material after 30 years (Figure 6B).

232 During extreme events in January (Figure 6C), the scrubland rill network was much less dense 
233 compared to long-term simulations. However, during extreme event in January some of the

234 partly infilled rills cut into adjacent field borders and continued eroding. Additionally, exclusively

235 soil erosion occurred downhill of the scrubland field border during extreme events in January.

236 Substituting vegetated pathways with bare soil (Figure 6A-ILS) increased connectivity between

237 parcels and concentration of overland flow from upper parcel in lower parcels under long-term

238 rainfall conditions (Figure 6B-ILS). During extreme events (Figure 6C, 6D -ILS) erosion $<0.01 \mathrm{~m}$

239 occurred along some rills in scrubland. Under ILS, equal erosion delivery was attained after 17

240 years in comparison to January extreme event. Soil redistribution after 17 and 30-years under

241 ILS was similar. For ILU and ILUS, equal erosion delivery was 7 and 6 years. Again the soil

242 erosion pattern of equal soil erosion delivery was similar to long-term soil redistribution pattern

243 (Figure 6E -ILU and ILUS).

244 Under ELU overland flow generated in upper parcel (scrubland, Figure 6A-ELU) caused less

245 intensive erosion on-site than vineyards parcels in stationary and more intensive production

246 scenarios in 30 years (Figure 6B). Furthermore, scrubland led to rill formation and their infilling

247 in lower parcel after 30 years (Figure 6B-ELU). In ELUS, combined land use and landscape

248 structure changes helped protect rill incision (Figure 6B ELUS), but as Figure 6B ELS shows,

249 change of landscape structure alone was not sufficient to prevent rill erosion. Under extreme

250 events, erosion was low along scrubland field borders, and downslope rills emerged only under

251 ELS. During the year when sediment export from long-term rainfall conditions equalled extreme

252 events, soil redistribution patterns was more related to long-term precipitation patterns (Figure

253 6, Supplementary Info 1).

254

255 3.3 External catchment dynamics

256 Sediment export is referred to external catchment dynamics, and is reported in section 3.1,

257 Table 1. In scenarios with intensified land use (ILU, ILUS), total sediment export over long-term

258 conditions was over 10-fold higher than BLUS, over 4-fold higher than ILS. Total sediment

259 export under extreme event in January was in ILU and ILUS over 2.6-fold higher than BLUS,

260 and over 1.6-fold higher than ILS. For scenarios with less intensive production than BLUS, long-

261 term sediment export at catchment outlet by 10\% (ELU), 40\% (ELS) and 50\% (ELUS) in 
comparison with BLUS sediment export.

264 Sediment export under all scenarios was increasingly stable over the first four years of model simulations, followed by sudden increases in the fifth year triggered by rainfall (Figure 7). The sediment export response to natural rainfall conditions differed between the modelled scenarios. Intensified scenarios responded with higher sediment production (i.e., erosion) and transport.

268 Soil export in ILUS more than doubled, and increased $\sim 1.5$-fold in ILU and ILS (Figure 7B). On the contrary, ELU exhibited increased sediment export than ELS. Threshold behaviours with different magnitudes of sediment response existed for all scenarios in several years (e.g., year 16, year 24).

272 Figure 7B compares sediment export by extreme events in January with long-term sediment export. Intensified scenarios reached the sediment export of BLUS within first 4 to 10 years (for

274 ILUS and ILS, respectively).

275

4. Discussion

277

278 4.1 Land management optimisation: understanding the impact on differing temporal scales

280 Comparing scenarios over different time scales showed that both external and internal catchment dynamics differed for long-term and extreme-event rainfall conditions. Mean and

282 variability of soil loss were greater after long-term rainfall events than extreme rainfall conditions. However, sediment export at the catchment outlet from a single extreme event (in

284 January) accounted for 89\% (BLUS) of long-term sediment export. Within-catchment and withinparcels erosional hotspots formed over the 30 year simulations. Hotspots' spatial distribution

286 differed for each land use scenario, while landscape structure influenced within-catchment (dis-) connectivity. Soil redistribution within parcels was strongly influenced by erosion from tillage

288 (David et al, 2014), which temporarily influences soil properties and micro-landforms (e.g., infilling rills, creating tillage rows) and thus, hydrology and associated sediment connectivity

290 along hillslopes. 
291 During extreme events, most of the catchment was connected. Soil erosion removed up to 0.01-

$292 \mathrm{~m}$ from almost the entire catchment independent of land use or landscape structure (except for

293 scrubland and some of the filed borders, grass strips, pathways). Land uses or landscape

294 structures sometimes acted as barriers or buffers under normal rainfall conditions, but were less

295 effective in damping overland flow and sediment trapping. Yet, effects of single extreme rainfall

296 events differed for October and January depending on soil-vegetation properties in the

297 respective month. In October, transport-limited deposition took place in some pathways,

298 whereas only transport and zero net erosion or deposition took place in January. Antecedent

299 conditions such as previous rainfall or tillage influenced sensitivity of sediment response to

300 seasonal changes in soil hydrological properties, demonstrated previously by monitoring studies

301 (e.g., Biddocu et al., 2017; Inoubli et al., 2017; Raclot et al., 2009, Smetanova et al., under

302 revision).

303

304 4.2 Land management optimisation: understanding effects of management measures under

305 different scenarios

306

307 We discuss the effect of land management on land-degradation based on area-specific

308 sediment budgets for both long-term and extreme events (Figure 8).

309 Chemical weeding led to erosion when applied on vineyards in all scenarios and timescales.

310 Mechanical weeding, was also a net source of sediment under extreme rainfall conditions in

311 January, but over 30 years, had nearly neutral sediment budget. According to David et al.

312 (2014), mechanical weeding caused three-times less sediment erosion compared to chemical

313 weeding over 100 years. However, extensive mechanical weeding in ELU without using

314 extensive landscape structures (such as in ELS) increased sediment export more than both

315 current land use and extensive landscape structure in ELS (Table 1). This confirms that land

316 use and landscape structure management must be used in combination to effectively decrease

317 both sediment production (i.e., erosion) from farmers' fields and sediment exported from the

318 catchment to river system.

319 Grass strips and vegetated strips were the most effective management strategies for trapping 
320 sediment at both temporal scales (and in 100 years as in David et al., 2014), but the sediment 321 trapped was highest for extreme events. Total area and spatial distribution of vegetated strips 322 was identical under BLUS; ILU and ILUS, but sediment trapping in vegetated strips decreased 323 with decreasing sediment production. Sediment trapping efficiency of vegetated strips differed 324 with (i) amount of sediment produced, (ii) spatial redistribution of landscape elements and land uses, and (iii) single (process) versus cumulative events (long-term processes). Trapping

326 efficiency was directly linked to sediment connectivity during extreme events and over the long327 term. This confirm previous findings that both sediment connectivity and sediment trapping 328 efficiency are dependent on spatial distribution of management (Collin et al., 2012; Gumiere et al., 2011; Mekonnen et al., 2015; Ramos et al., 2010). Using a raster-based approach allowed

330 us to assess sediment production and transport at individual parcel scale at both temporal

331 scales (example in Figure 6). However, we did not calculate soil loss and effectiveness of 332 measures for each farmer at different time scales, which is possible and recommended for 333 supporting decision-making schemes (Souchère et al., 2010). At the catchment scale, soil

334 surface properties drove sediment export regardless of land use (David et al., 2014). Therefore, management techniques aimed at the soil surface can reduce soil erosion. Such approaches

336 include straw mulch or intercropping, and are known to decrease soil erosion under long-term 337 and extreme rainfall conditions (Biddocu et al., 2014, 2016, 2017; Blavet et al., 2009; Cerdà et 338 al., 2016; Gómez et al., 2009, 2014; Kosmas et al., 1997; Prosdocimi et al., 2016; Raclot et al., 339 2009; Ramos et al., 2007; Rodrigo-Comino et al., 2016; Ruiz-Colmenro et al., 2011).

340 Management strategies can be either (i) permanently incorporated in land use scenarios, or (ii) 341 used in conjunction with others (e.g., geotextiles, mobile sediment trapping barriers) as ad-hoc 342 measures during extreme events (Sherrif et al., 2016).

344 4.3 Pathways for applicable optimisation for land-degradation neutral management

346 Our results suggest that using multiple temporal, spatial and management scales to evaluate 347 soil erosion and connectivity can significantly improve existing modelling approaches (Bussi et 348 al., 2016; Collin et al., 2012; David et al., 2014; Gumiere et al., 2014; Mullan et al., 2016; Nunes 
et al., 2013; Paroissien et al, 2015; Ramos et al., 2015; Rodriguez-Lloveras et al., 2016; Ronfort

350 et al., 2011; Routschek et al., 2014). Our approach includes temporally- and spatially-adjusted

351 measures that are applicable for meeting soil erosion and land degradation neutrality targets

352 (The Global Mechanism of UNCCD, 2016). We demonstrate that proposing land degradation

353 neutrality measures in agricultural catchments is extremely complex due to (i) natural variability

354 of catchment responses to normal rainfall conditions and extreme events, and (ii) variability in

355 cumulative response depending on the spatial distribution of selected measures. Furthermore,

356 we showed that (iii) the same sediment export (sediment yield) values represented different

357 patterns of soil erosion and deposition within a catchment. The complexity of applying measures

358 to reduce land degradation is reinforced by differing interests and management aims of each

359 stakeholder (e.g., farmer or watershed manager; Smetanová et al., 2018). Therefore, modelling

360 approaches applied on differing spatial and temporal scales are valuable aid for participative

361 decision making on best practice management (Hewett et al., 2018, Keesstra et al., 2018).

363 5. CONCLUSION

365 Our research proved, that tailoring specific management strategies for specific spatial and temporal scales might be suitable in order to achieve land degradation neutral management.

367 Our research contributions included the following in regards to attaining land degradation neutrality goals:

1. Managing changes to land use or cover won't appropriately serve land degradation neutrality targets at the catchment scale (sub-national level). It is essential to include landscape structure change and connectivity management into land use scenarios.

2. Internal and external catchment dynamics differ for long-term and extreme events, and therefore multiple temporal, spatial, and management scales must be compared and incorporated in to planning adaptive management for land degradation. Optimally, this will span from farm- to catchment-scales, as well as sub-national levels.

3. Modelling approaches such as LandSoil enable comparison of management efficiency for both long- and extreme event-scales. Additionally, the model improves selection of 
381 We suggest that holistic land degradation neutrality management can be selected by using

382 multi-scale consideration based on models incorporated in participative decision making. Using such inputs will bring multiple co-benefits fostering life on land, including avoiding, reducing and reversing land degradation processes.

Acknowledgement

This work benefits from the financial support of ANR-08-VULN-006 (LANDSOIL project) and MESOEROS21 (ANR-06-VULN-012), ORE OMERE, MISTRALS/Sicmed R_Osmed and MASCC (funded by ARIMNET2). Anna Smetanová received Marie-Curie FP7 COFUND People

390 Programme AgreenSkills fellowship (grant 267196). Author thank to Dr. Mitchell Donovan for his helpful comments and remarks.

References

394 Biarnès A, Colin F. 2006. Methodology for assessing the hydrological impact of weed control practices with a view to management of Mediterranean vine growing catchments. International

396 Journal of Sustainable Development 9, 161-179. doi: 10.1504/IJSD.2006.011639

397 Biddocu M, Ferraris S, Pitacco A, Cavallo E. 2017. Temporal variability of soil management

398 effects on soil hydrological properties, runoff and erosion at the field scale in a hillslope 399 vineyard, North-West Italy. Soil \& Tillage Research 165, 46-58.

400 Biddoccu M, Ferraris S, Opsi F, Cavallo E. 2016. Long-term monitoring of soil management 401 effects on runoff and soil erosion in sloping vineyards in Alto Monferrato (North-West Italy). Soil

402 \& Tillage Research 155, 176-189. doi:10.1016/j.still.2015.07.005.

403 Biddoccu M, Opsi F, Cavallo E. 2014. Relationships between runoff and soil losses with rainfall 404 characteristics and a long-term soil management practices in a hilly vineyard (Piedmont, NW 405 Italy). Soil Science and Plant Nutrition 60, 92-99. doi: 10.1080/00380768.2013.862488.

406 Blavet D, De Noni G, Le Bissonnais Y, Leonard M, Maillo L, Laurent JY, Asseline J, Leprun JC, 
407 Arshad MA, Roose E. 2009. Effect of land use and management on the early stages of soil

408 water erosion in French Mediterranean vineyards. Soil \& Tillage Research 106, 124-136.

409 Bussi G, Dadson SJ, Prudhomme C, Whitehead P. 2016. Modelling the future impacts of

410 climate and land-use change on suspended sediment transport in the River Thames (UK).

411 Journal of Hydrology 542, 357-372. doi: 10.1016/j.jhydrol.2016.09.010

412 Cerdà A, González-Pelayo O, Giménez-Morera A, Jordán A, Pereira P, Novara A, Brevik EC,

413 Prosdocimi M, Mahmoodabadi M, Keesstra S, García Orenes F, Ritsema C. 2016. The use of

414 barley straw residues to avoid high erosion and runoff rates on persimmon plantations in

415 Eastern Spain under low frequency - high magnitude simulated rainfall events. Soil Research

$416 \quad 54,154-165$.

417 Ciampalini R, Billi P, Follain S, Le Bissonnais Y, Ferrari G, Borselli L. 2011. Long-term soil

418 erosion analysis on the terrace systems of the archaeological area of Aksum (Ethiopia) (1800

419 BC - today). IAG Regional meeting (Addis Abeba).

420 Ciampalini R, Follain S, Le Bissonnais Y. 2012. LandSoil: a model for the analysis of erosion

421 impact on agricultural landscape evolution. Geomorphology 175, 25-37. doi:

422 10.1016/j.geomorph.2012.06.014

423 Ciampalini R, Follain S, Cheviron B, Le Bissonnais Y, Couturier A, Walter C. 2017. Local

424 sensitivity analysis of the LandSoil erosion model applied on a virtual catchment". In: Srivastava

425 P, Petropoulos G. (Eds.) Sensitivity Analysis in Earth Observation Modelling, Elsevier, pp 55-73.

426 Chartin C, Bourennane H, Salvador-Blanesa S, Hinschberger F, Macaire J-J. 2011.

427 Classification and mapping of anthropogenic landforms on cultivated hillslopes using DEMs and

428 soil thickness data - Example from the SW Parisian Basin, France. Geomorphology 135, 8-20.

429 doi: 10.1016/j.geomorph.2011.07.020

430 Collin F, Moussa R, Louchart X. 2012. Impact of the spatial arrangement of land management

431 practices on surface runoff for small catchments. Hydrological Processes 26, 255-271. doi:

$43210.1002 /$ hyp.8199

433 Cosandey C, Robinson M. 2000. Hydrologie continentale. Armand Colin, Paris, 2000, 368 p.

434 Coulouma G, Boizard H, Trotoux G, Lagacherie P, Richard G. 2006. Effect of deep tillage for

435 vineyard establishment on soil texture: a case study in southern France. Soil \& Tillage Research 
437 Coulthard TJ, Van De Wiel MJ. 2017. Modelling long term basin scale sediment connectivity,

438 driven by spatiall and land use changes. Geomorphology 277, 265-281. doi:

439 10.1016/j.geomorph.2016.05.027

440 David M, Follain S, Ciampalini R, Le Bissonnais Y, Couturier A, Walter C. 2014. Simulation of 441 medium-term soil redistributions for different land use and landscape design scenarios within a

442 vineyard landscape in Mediterranean France. Geomorphology 214, 10-21. doi:

$443 \quad 10.1016 /$ j.geomorph.2014.03.016

444 Dominati E, Patterson M, Mackay A. 2010. A framework for classifying and quantifying the 445 natural capital and ecosystem services of soils. Ecological Economics 69, 1858-1868. doi:

446 10.1016/j.ecolecon.2010.05.002

447 Follain S, Minasny B, McBratney AB, Walter C. 2006. Simulation of soil thickness evolution in a 448 complex agricultural landscape at fine spatial and temporal scales. Geoderma 133, 71-86.

449 Furlan A, Poussin J-C, Mailhol J-C, Le Bissonnais Y, Gumiere SJ. 2012. Designing

450 management options to reduce surface runoff and sediment yield with farmers: An experiment

451 in south-western France. Journal of Environmental Management 96, 74-85.

452 Fryirs K. 2013. (Dis)Connectivity in catchment sediment cascades: a fresh look at the sediment 453 delivery problem. Earth Surface Processes \& Landforms 38, 30-46. doi: 10.1002/esp.3242

454 García-Ruiz JM, Beguería S, Lana-Renault N, Nadal-Romero E, Cerda A. 2017. Ongoing and 455 emerging questions in water erosion studies. Land Degradation \& Development 28, 5-21.

456 Gómez JA, Sobrinho TA, Giráldez JV, Fereres E. 2009. Soil management effects on runoff, 457 erosion and soil properties in an olive grove of Southern Spain. Soil \& Tillage Research. 102, 5458 13. doi:10.1016/j.still.2008.05.005.

459 Gómez JA, Vanwallenghem T, De Hoces A, Taguas EV. 2014. Hydrological and erosive

460 response of a small catchment under olive cultivation in a vertic soil during a five-year period:

461 implications for sustainability. Agric. Ecosyst. Environ. 188, 229-244.

462 Guix-Hébrard N, Voltz M, Trambouze W, Garnier F, Gaudillère JP, Lagacherie P. 2007.

463 Influence of watertable depths on the variation of grapevine water status at the landscape scale. 
464 European Journal of Agronomy 27, 187-196. doi: 10.1016/j.eja.2007.03.005

465 Gumiere SJ, Bissonnais Y, Raclot D, Cheviron B. 2011. Vegetated filter effects on

466 sedimentological connectivity of agricultural catchments in erosion modelling: A review. Erath

467 Surface Processes and Landforms 36, 3-19.

468 Gumiere SJ, Bailly J-S, Cheviron B, Raclot D, Le Bissonnais Y, Rousseau A. 2014. Evaluating

469 the impact of the spatial distribution of land management practices on water erosion: case study

470 of a Mediterranean catchment. Journal of Hydrology Engineering. doi:

$471 \quad$ 10.1061/(ASCE)HE.1943-5584.0001076, C5014004.

472 Hewett C, Simpson C, Wainwright J, Hudson S. 2018. Communicating risk to infrastructure due

473 to soil erosion: a bottom up approach. Land Degradation \& Development 29, 1282-1294.

474 Inoubli N, Raclot D, Moussa R, Habaieb H, Le Bissonnais Y. 2016. Soil cracking effects on

475 hydrological and erosive processes in Mediterranean cultivated vertisols. Hydrological Process,

$47630,4154-4167$.

477 Jenson SK, Domingue JO. 1988. Extracting topographic structure from digital elevation data for

478 geographic information system analysis. Photogrammetric Engineering and Remote Sensing

$47954,1593-1600$.

480 Keesstra SD, Bouma J, Wallinga J, Tittonell P, Smith P, Cerdà A, Montanarella L, Quinton JN,

481 Pachepsky Y, van der Putten WH, Bardgett JD, Moolenaar S, Mol G, Jansen B, Fresco, LO.

482 2016. The significance of soils and soil science towards realization of the United Nations

483 Sustainable Development Goals. Soil 2, 111-128. doi: 10.5194/soil-2-111-2016

484 Keesstra SD, Nunes JP, Novara A, Finger D, Avelar D, Kalantari Z, Cerda A. 2018. The superior effect of nature based solutions in land management for enhancing ecosystem

486 services. Science of the Total Environment 610-611, 997-1009. doi:

487 10.1016/j.scitotenv.2017.08.077

488 Koch A, Field D, McBratney A B, Adams M, Hill R, Craw-ford J, Minasny B, Lal R, Abbott L, 489 O'Donnel A, Angers D, Baldock J, Barbier E, Binkley D, Parton W, Wall DH, Bird M, Chenu C, 490 Flora CB, Goulding K, Grunwald S, Hempel J, Jastrow J, Lehmann J, Lorenz K, Morgan CL, 491 Whitehead D, Young I, Zimmermann M. 2013. Soil security: solving the global soil crisis. Global 492 Policy 4, 434-441. doi: 0.1111/1758-5899.12096 
493 Kosmas C, Danalatos N, Cammeraat LH, Chabart M, Diamantopoulos J, Farand R, Gutierrez L, 494 Jacob A, Marques H, Martinez-Fernandez J, Mizara A, Moustakas N, Nicolau JM, Oliveros C, 495 Pinna G, Puddu R, Puigdefabregas J, Roxo M, Simao A, Stamou G, Tomasi N, Usai D, Vacca 496 A. 1997. The effect of land use on runoff and soil erosion rates under Mediterranean conditions.

497 CATENA, 29, 45-59.

498 Lacoste M, Viaud V, Michot D, Walter C. 2016. Model-based evaluation of impact of soil

499 redistribution on soil organic carbon stocks in a temperate hedgerow landscape. Earth Surface

500 Processes and Landforms, 41, 1536-1549. doi: 10.1002/esp.3925

501 Lal R. 2004. Soil Carbon Sequestration Impacts on Global Climate Change and Food Security.

502 Science 304, 1623-1627. doi: 10.1126/science.1097396

503 Leonard J, Andrieux P. 1998. Infiltration characteristics of soils in Mediterranean vineyards in 504 southern France. Catena 32, 209-223. doi: 10.1016/S0341-8162(98)00049-6

505 Levavasseur F, Bailly J-S, Lagacherie P. 2016. Are ditch networks optimised for mitigating rill 506 erosion in cultivated Mediterranean landscapes? A numerical experiment. Land Use Policy 50, $507 \quad 441-448$.

508 Meteo France, 2018. Pluies extrêmes en France métropolitaine.

509 http://pluiesextremes.meteo.fr/france-metropole/Fantastique-chute-de-pluie-sur-Perpignan.html. $510 \quad$ Accessed: 15 May 2018.

511 McBratney AB, Field DJ, Koch A. 2014. The dimensions of soil security. Geoderma 213, 203512 213. doi: 10.1016/j.geoderma.2013.08.013

513 Mekonnen M, Keesstra SD, Stroosnijder L, Baartman JEM, Maroulis J. 2015. Soil conservation 514 through sediment trapping: A review. Land Degradation \& Development 26, 544-556.

515 Montanarella L, Pennock DJ, McKenzie N, Badraoui M, Chude V, Baptista I, Mamo T, 516 Yemefack M, Singh Aulakh M, Yagi K, Young Hong S, Vijarnsorn P, Zhang G-L, Arrouays D,

517 Black H, Krasilnikov P, Sobocká J, Alegre J, Roberto Henriquez C, de Lourdes Mendonça-

518 Santos M, Taboada M, Espinosa-Victoria D, Al Shankiti A, Alavi Panah SK, El Mustafa Elsheikh

519 EA, Hempel J, Camps Arbestain M, Nachtergaele F, Vargas R. 2016. World's soils are under

520 threat. Soil 2, 79-82. doi: 10.5194/soil-2-79-2016

521 Mullan D, Vandaele K, Boardman J, Meneely J, Crossley LH. 2016. Modelling the effectiveness 
522 of grass buffer strips in managing muddy floods under a changing climate. Geomorphology

523 102-120. doi: 10.1016/j.geomorph.2016.07.012

524 Nunes JP, Seixas J, Keizer JJ. 2013. Modelling the response of within-storm runoff and erosion

525 dynamics to climate change in two Mediterranean watersheds: A multi-model, multi-scale

526 approach to scenario design and analysis. Catena 102, 27-39. doi:

527 10.1016/j.catena.2011.04.001

528 Orr BJ, Cowie AL, Castillo Sanchez VM, Chasek P, Crossman ND, Erlewein A, Louwagie G,

529 Maron M, Metternicht GI, Minelli S, Tengberg AE, Walter S, Welton S. 2017. Scientific

530 Conceptual Framework for Land Degradation Neutrality. A Report of the Science-Policy

531 Interface. United Nations Convention to Combat Desertification (UNCCD), Bonn, Germany.

532 ISBN 978-92-95110-42-7 (hard copy), 978-92-95110-41-0 (electronic copy).

533 Paroissien J-B, Darboux F, Devillers B, Mouillot F, Raclot D, Le Bissonnais Y. 2015. A method

534 for modelling the effects of climate and land use changes on erosion and sustainability of soil in

535 a Mediterranean watershed (Languedoc, France). Journal of Environmental Management 150,

536 57-68. doi: 10.1016/j.jenvman.2014.10.034

537 Peel, M.C., Finlayson, B.L., McMahon, T.A. 2007. Updated world map of the Köppen-Geiger

538 climate classification. Hydrology \& Earth System Sciences, 11, 1633-1644.

539 Prosdocimi, M., Cerdà, A., Tarolli, P., 2016. Soil water erosion on Mediterranean vineyards: a

540 review. Catena 141 (2016), 1-21.

541 Raclot D, Le Bissonnais Y, Annabi M, Sabir M, Smetanova A. 2018. Main issues for preserving

542 Mediterranean soil resources from water under global change. Land Degradation \&

543 Development 29, 789-799.

544 Raclot D, Le Bissonnais Y, Louchart Y, Andrieux P, Moussa R, Voltz M. 2009. Soil tillage and 545 scale effects on erosion from fields to catchment in a Mediterranean vineyard area. Catena 66, $546 \quad 198-210$.

547 Ramos MC, Martínez-Casasnovas JA. 2007. Soil loss and soil water content affected by land

548 levelling in Penedès vineyards, NE Spain. Catena 71, 210-217.

549 Ramos MC, Martínez-Casasnovas JA. 2010. Effects of field reorganisation on the spatial

550 variability of runoff and erosion rates in vineyards of Northeastern Spain. Land Degradation \& 
552 Ramos MC, Benito C, Martínez-Casasnovas JA. 2015. Simulating soil conservation measures

553 to control soil and nutrient losses in a small, vineyard dominated, basin. Agriculture,

554 Ecosystems \& Environment, 213, 194-208.

555 Rodrigo-Comino J, Iserloh T, Morvan X, Malam Issa O, Naisse C, Keesstra SD, Cerdà A,

556 Prosdocimi M, Arnáez J, Lasanta T, Concepión Ramos M, Marqués MJ, Ruiz-Colmenero M,

557 Bienes R, Ruiz Sinoga JD, Seeger M, Ries JB.2016. Soil Erosion Processes in European

558 Vineyards: A Qualitative Comparison of Rainfall Simulation Measurements in Germany, Spain

559 and France. Hydrology 3, 6. doi:10.3390/hydrology3010006

560 Rodríguez-Blanco ML, Arias R, Taboada-Castro MM, Nunes JP, Keizer JJ, Taboada-Castro T.

561 2016. Potential Impact of Climate Change on Suspended Sediment Yield in NW Spain: A Case

562 Study on the Corbeira Catchment. Water 8, 444. doi: 10.3390/w8100444

563 Rodriguez-Lloveras X, Buytaert W, Benito G. 2016. Land use can offset climate change induced

564 increases in erosion in Mediterranean watersheds. Catena 143, 244-255. doi:

$565 / 10.1016 /$ j.catena.2016.04.012

566 Ronfort C, Souchère V, Martin P, Sebillotte C, Castellazzi MS, Barbottin A, Meynard JM, Laignel

567 B. 2011. Methodology for land use change scenario assessment for runoff impacts: A case

568 study in a north-western European Loess belt region (Pays de Caux, France). Catena 86, 36-

569 48. doi:10.1016/j.catena.2011.02.004

570 Routschek A, Schmidt J, Enke W, Deutschlander T. 2014a. Future soil erosion risk — Results of

571 GIS-based model simulations for a catchment in Saxony/Germany. Geomorphology 206, 299-

572 306. doi: 10.1016/j.geomorph.2013.09.033

573 Routschek A, Schmidt J, Kreienkamp F. 2014b. Impact of climate change on soil erosion - A

574 high-resolution projection on catchment scale until 2100 in Saxony/Germany. Catena 121, 99-

575 109. doi: 10.1016/j.catena.2014.04.019

576 Serpa D, Nunes JP, Santos J, Sampaio E, Jacinto R, Veiga S, Lima JC, Moreira M, Corte-Real

577 J, Keizer JJ, Abrantes N. 2015. Impacts of climate and land use changes on the hydrological

578 and erosion processes of two contrasting Mediterranean catchments. Science of Total

579 Environment 538, 64-77. doi: 10.1016/j.scitotenv.2015.08.033 
580 Sherriff SC, Rowan JC, Fenton O, Jordan P, Melland AR, Mellander P-E, Ó hUallacháin D.

581 2016. Storm Event Suspended Sediment-Discharge Hysteresis and Controls in Agricultural

582 Watersheds: Implications for Watershed Scale Sediment Management. Environmental Sciences

583 \& Technology, 50, 1769-1778. doi: 10.1021/acs.est.5b04573

584 Smetanová A, Paton E, Maynard C, Tindale S, Fernandez-Getino A-P, Marques MJ, Bracken L,

585 Le Bissonnais Y, Keesstra S. 2018. Stakeholders' perception of the relevance of water and

586 sediment connectivity in water and land management. Land Degradation \& Development, doi:

$587 \quad 10.1002 / \mathrm{ldr} .2934$

588 Smetanová A, Le Bissonnais Y, Raclot D, Nunes JP, Licciardello F, Le Bouteiller C, Latron J,

589 Rodríguez-Caballero E, Mathys N, Klotz S, Mekki I, Gallart F, Solé Benet A, Pérez Gallego N,

590 Andrieux P, Moussa R, Planchon O, Marisa Santos J, Alshihabi O, Chikhaoui M., Follain S.,

591 2018. Patterns of temporal variability and time compression of sediment yield in small

592 Mediterranean catchments. Soil Use \& Management 34, 388-403. doi: 10.1111/sum.12437.

593 Souchère V, King D, Daroussin J, Papy F, Capillon A. 1998. Effects of tillage on runoff

594 directions: consequences on runoff contributing area within agricultural catchments. Journal of

595 Hydrology 206, 256-267.

596 Souchère V, Millair L, Echeverria J, Bousquet F, Le Page C, Etienne M. 2010. Co-constructing

597 with stakeholders a role-playing game to initiate collective management of erosive runoff risks at

598 the watershed scale. Environmental Modelling \& Software 25, 1359-1370.

599 Stroosnijder, L. 2005. Measurement of erosion: Is it possible? CATENA, 64, 162-173

600 The Global Mechanism of UNCCD. 2016. Achieving Land Degradation Neutrality at the Country

601 Level: Building Blocks for LDN Target Setting. Bonn, Germany. ISBN 978-92-95110-31-1 
Figure description:

Figure 1. Study area (A), land use (B), and landscape structures (C)

Figure 2: Flowchart of numerical experiment in LandSoil. Model inputs were digital elevation model, dynamic soil properties, seven land management scenarios, and rainfall. Two temporal (long-term, single event) and two spatial dynamics (internal and external) were considered. Red triangle indicates management priorities of a farmer, inverted red triangle priorities of a watershed manager. Outputs related to internal $(\mathrm{v})$ and external (inverted v) catchment dynamics were produced for each scenario.

Figure 3. Land management allocation matrix.

Figure 4. The full 30 years of precipitation data plotted over time. First 20 years (red frame) are empirically measured rainfall events in Roujan (1992-2012), while the last 10 years are extension of the empirical dataset. The red star represents the amount of rainfall during the extreme event (435 $\mathrm{mm} / 24 \mathrm{~h})$ measured in Perpignan in 1915.

Figure 5. Internal catchment dynamics under current land use and landscape structure (BLUS) A: Land use and landscape structure, B-F: Erosion and deposition: (B) after 30 years of normal rainfall conditions, (C) after an extreme event in January, (D) after an extreme event in October. (E) internal catchment dynamics in year (indicated by number) when sediment export by the long-term rainfall series matches that of an extreme event in January, and $(F)$ same as $E$, but for an extreme event in October. An elevation change legend (bottom right) shows deposition as positive, erosion as negative, and anything $<10^{-12} \mathrm{~m}$ and $>-10^{-12} \mathrm{~m}$ as "no erosion, no deposition".

Figure 6. Internal catchment dynamics in one selected catchment segment Land use and landscape structure(A), and erosion and deposition on different time scales (B-F) under different scenarios (indicated by rows) are shown in the selected catchment segment (locator figure, left bottom). Time scales: (B) 30 years under normal rainfall conditions, (C) an extreme event in January, and (D) an extreme event in October. In columns E and F, internal catchment dynamics are shown for the year when catchment outlet sediment export under long-term rainfall series met that of 
an extreme event $(E)$ in January and $(F)$ in October.

Baseline scenario (B) represents steady production under current land use (LU) and landscape structure (S). More intensive (I) production than steady production is represented by ILU, ILS, ILUS scenario, less intensive (E) production by ELU, ELS, ELUS.

An elevation change legend (bottom right) shows deposition as positive, erosion as negative, and anything $<10^{-12} \mathrm{~m}$ and $>-10^{-12} \mathrm{~m}$ ) as "no erosion, no deposition".

Figure 7. External catchment dynamics

(A) Area specific sediment yield at the catchment outlet $\left(10^{-2} \mathrm{Mg} \cdot \mathrm{km}^{-2}\right)$ over 30 years. (B) Comparison between sediment delivery over long-term (30 years) and extreme events in January (arrow). Baseline scenario (B) represents steady production under current land use (LU) and landscape structure (S). More intensive (I) production than steady production is represented by ILU, ILS, ILUS scenario, less intensive € production by ELU, ELS, ELUS.

Figure 8. Land management effect on land degradation under different scenarios and temporal scales. Area-specific sediment budget within landscape management $\left(10^{-2} \mathrm{Mg} \cdot \mathrm{km}^{-2}\right)$ is plotted for long-term (30 years, $x$-axis), and an extreme event in January (y-axis). Erosion is plotted in red and orange, deposition in green and blue. 
C
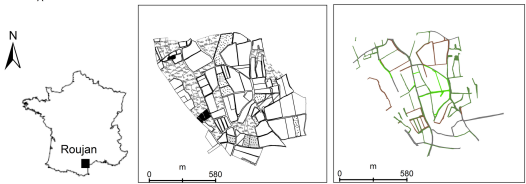

Baseline scenario: (A) land use and (B) landscape structure

$\square$ vineyards - mechanical weeding $\square$ fruit trees

- vineyards - chemical weeding

c] annual crops - tillage as scrubland

Eannual crops - no tillage
= pathway - bare sol

= building

= pathway - vegetated soil $=$ paved rosd

n grass strip 


\begin{tabular}{|c|c|c|c|c|}
\hline \multirow{2}{*}{\multicolumn{2}{|c|}{ Management }} & \multicolumn{3}{|c|}{ Narrative } \\
\hline & & Stationary & More intensive & Less intensive \\
\hline \multirow{3}{*}{ Landuse (LU) } & Area: vineyards and crop & \multirow{7}{*}{ ש } & & \\
\hline & Area: chemical weeding & & & \\
\hline & Area: no tillage & & & \\
\hline \multirow{4}{*}{$\begin{array}{l}\text { Landscape } \\
\text { structure (LS) }\end{array}$} & Field unit surface & & & \\
\hline & Linear structure density & & & \\
\hline & Downslope tillage direction & & & \\
\hline & Area: grass strips & & & \\
\hline \multicolumn{5}{|c|}{$\begin{array}{l}\text { Scenarios were build according to three narratives: (B) - stationary production (representing current conditions), } \\
\text { (I) more intensive production and (E) less intensive production than current conditions. Land use (LU) and/or } \\
\text { landscape structure (LS) management was modified by increase ( } \uparrow \text { ) or decrease }(\downarrow) \text { in total area, and change in } \\
\text { spatial allocation of LU and/or LD management in comparison with stationary production (-). The abbreviations of } \\
\text { resulting seven scenarios (BLUS, ILU, ILS, ILUS, ELU, ELS, ELUS) indicate the narrative (B, I, S) and } \\
\text { management (LU, LS, or LUS- both LU and LS). Detailed rules on allocation are in David et al. (2014). Spatial } \\
\text { allocation of BLUS is plotted in Figure 5A (BLUS), and remaining scenarios in Supplementary Info 1.1A-1.6A. }\end{array}$} \\
\hline
\end{tabular}




\section{Land Management}

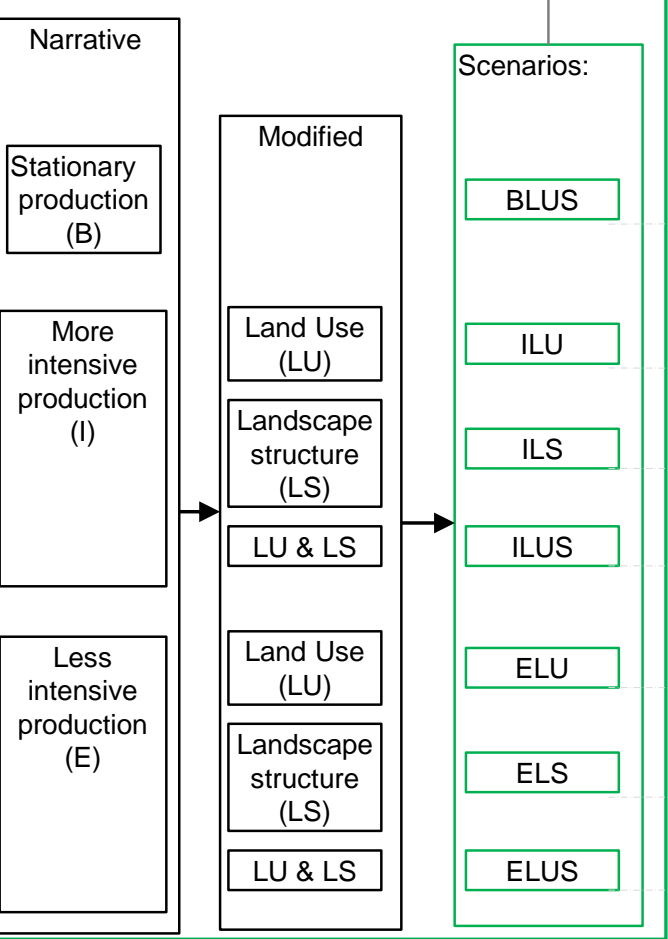

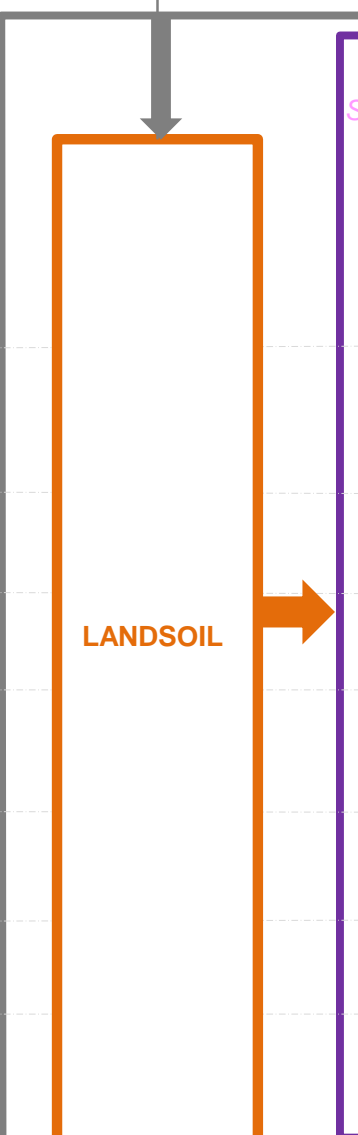

\section{OUTPUTS}

Spatial dynamics $\Delta \quad \begin{gathered}\text { Internal catchment dynamics (v) } \\ \text { (Spatial distribution of soil loss) }\end{gathered}$
$\vee \wedge$
$\vee \wedge$
$\vee \wedge$

$\vee \wedge$

$\vee \wedge$

$\vee \wedge$

$\vee \wedge$

$\vee \wedge$

$\vee \wedge$

$\vee \wedge$

$\vee \wedge$

$\vee \wedge$

$\vee \wedge$

$\vee \wedge$

$\vee \wedge$

$\vee \wedge$

$\vee \wedge$

$\vee \wedge$

$\vee \wedge$

$\vee \wedge$

$\vee \wedge$ 


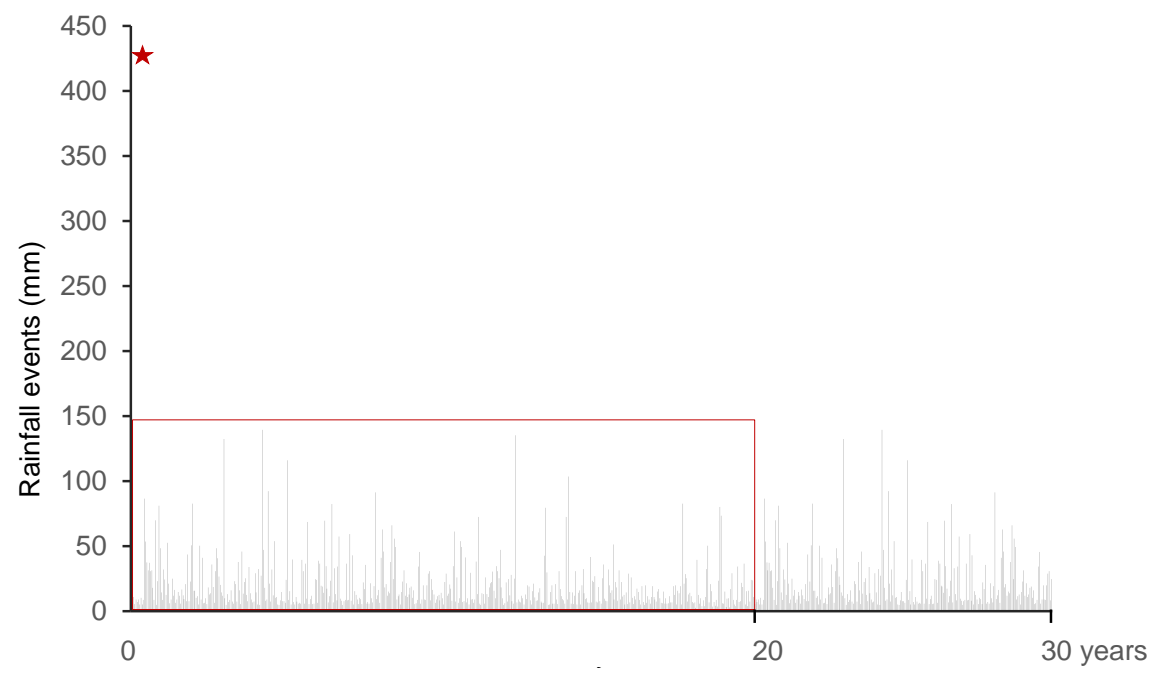



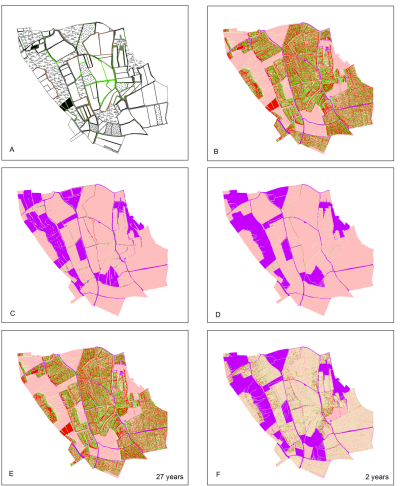

Land use and kandscape structure

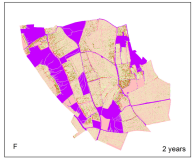

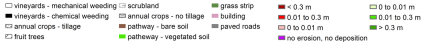



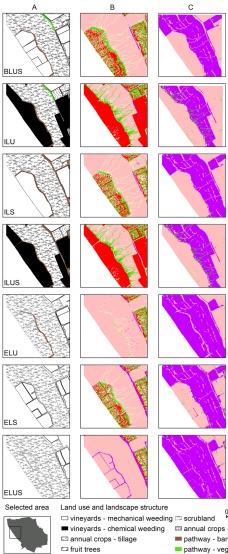

Land use and landscape structure

$\square$ wineyards - mechancal wooding
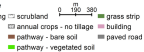

co annusl crops - sltares

$\square$ fruit trees in pothway - vegetabed soi
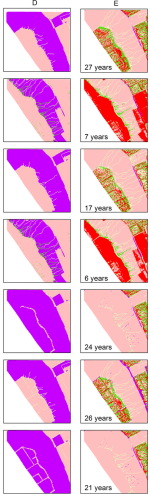

\section{Erusian}

$\mathbf{m}<0.3 \mathrm{~m}$

=001 $00.3 \mathrm{~m}$

Dom001 it

En no wraich, no depasition

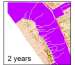

5 years
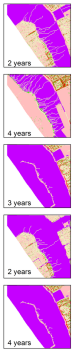

Accumulation

ए0100.01 m

0.01 to $0.3 \mathrm{~m}$ en $>0.3 \mathrm{~m}$

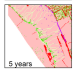




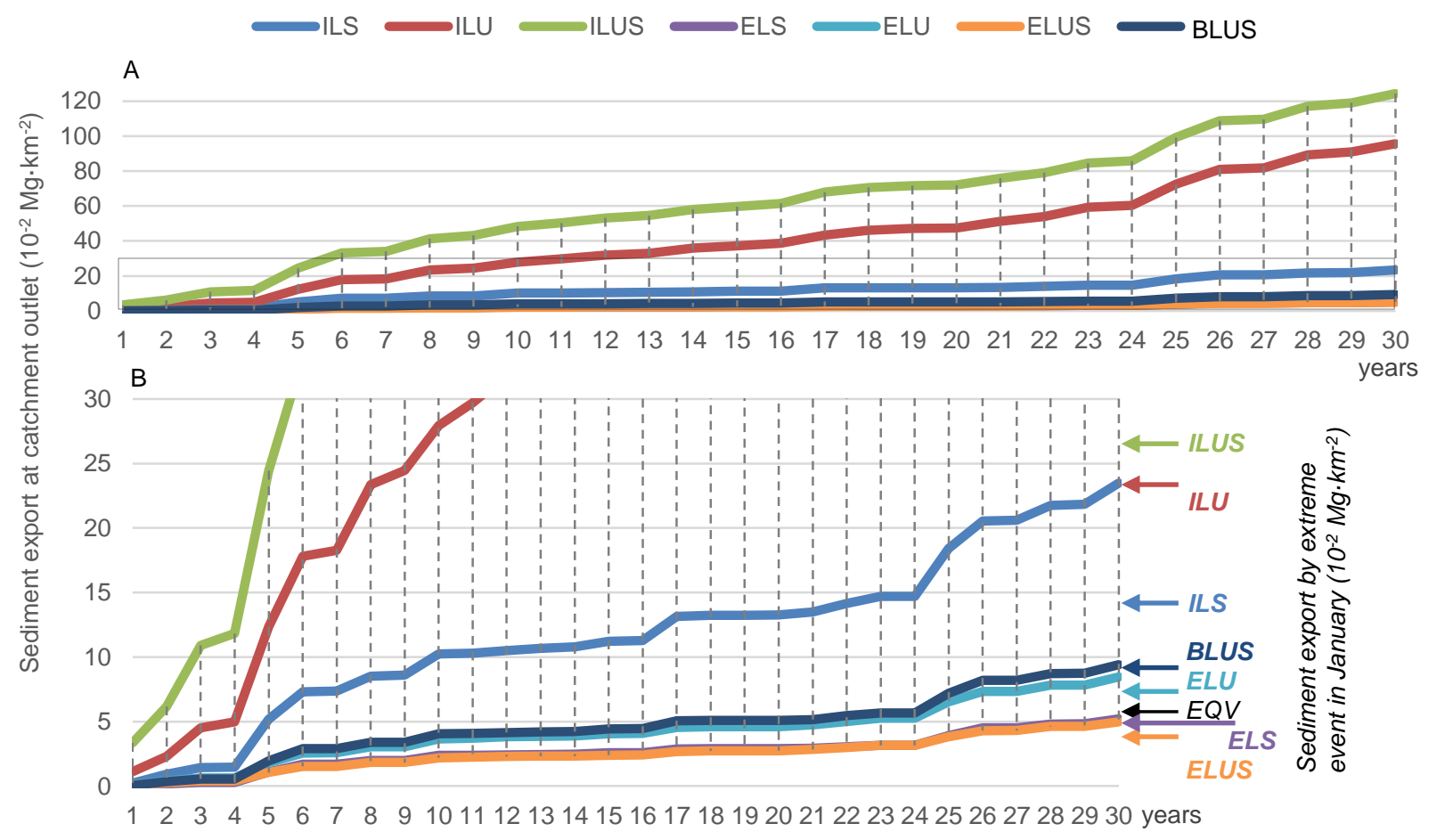




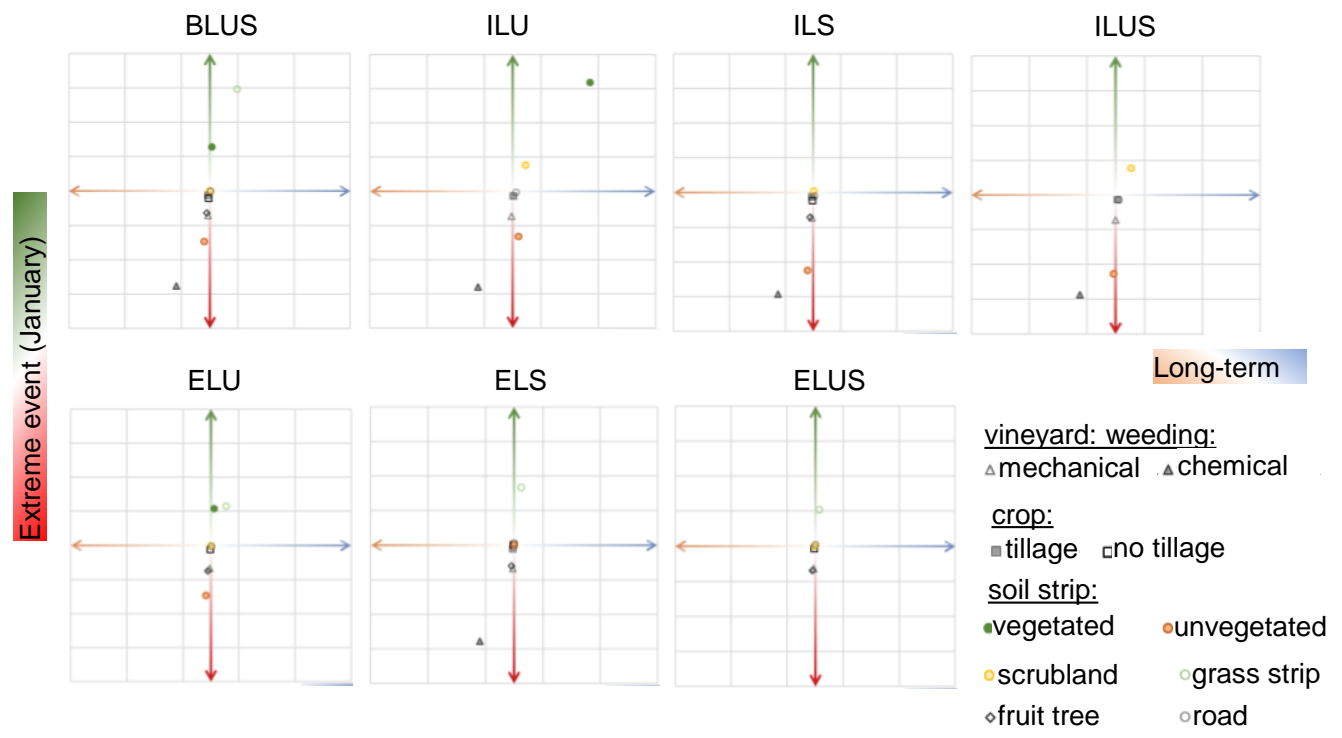


Table 1. Mean soil loss for the catchment and soil export at catchment outlet under each scenario

\begin{tabular}{|c|c|c|c|c|c|c|c|c|c|c|c|}
\hline & I on & term ero & & & & & Extre & vent in & & & \\
\hline & Luing & 1016 & & & Janu & & & & Octol & & \\
\hline & $\begin{array}{l}\text { Mean soil } \\
\text { loss }^{*}\end{array}$ & Soil expor & $t$ at outlet & $\begin{array}{c}\text { Mean soil } \\
\text { loss }^{*}\end{array}$ & Soil expo & $t$ at outlet & Equal & $\begin{array}{l}\text { Mean soil } \\
\text { loss* }^{*}\end{array}$ & Soil expc & $t$ at outlet & Equal \\
\hline & $10^{-3} \mathrm{~m}$ & $\mathrm{Mg}$ & $\begin{array}{c}10^{-2} \\
\mathrm{Mg} \cdot \mathrm{km}^{-2}\end{array}$ & $10^{-3} \mathrm{~m}$ & $\mathrm{Mg}$ & $\begin{array}{c}10^{-2} \\
\mathrm{Mg} \cdot \mathrm{km}^{-2}\end{array}$ & years & $10^{-3} \mathrm{~m}$ & $\mathrm{Mg}$ & $\begin{array}{c}10^{-2} \\
\mathrm{Mg} \cdot \mathrm{km}^{-2}\end{array}$ & years \\
\hline LUS & $0.69 \pm 38.97$ & 856 & & $0.62 \pm 2$ & 76 & & 26.7 & 0.04 & 46 & & 1.6 \\
\hline ILU & $7.05 \pm 80.47$ & 8700.59 & 91.70 & $1.62 \pm 4.39$ & 1996.81 & 21.05 & 6.9 & $1.18 \pm 4.38$ & 1456.43 & 15.35 & 5.0 \\
\hline ILS & $1.73 \pm 35.69$ & 2135.83 & 22.51 & $0.99 \pm 2.16$ & 1216.83 & & 17.1 & & 112.82 & & 1.6 \\
\hline ILUS & $9.17 \pm 52.68$ & 11309.58 & 119.20 & $1.89 \pm 3.44$ & 2334.57 & 24.60 & 6.2 & $1.17 \pm 3.26$ & 1445.42 & 15.23 & 3.8 \\
\hline ELU & $0.62 \pm 25.16$ & 769.80 & 8.11 & $0.50 \pm 2.01$ & 614.55 & 6.48 & 23.9 & $0.07 \pm 1.16$ & 88.06 & 0.93 & 3.4 \\
\hline ELS & $0.38 \pm 35.01$ & 469.59 & 4.95 & $0.33 \pm 3.10$ & 412.83 & 4.35 & 26.4 & $0.03 \pm 1.38$ & 36.87 & 0.39 & 2.4 \\
\hline ELUS & $0.36 \pm 19.43$ & 449.81 & 4.74 & $0.26 \pm 2.47$ & 318.81 & 3.36 & 21.3 & $0.05 \pm 1.35$ & 57.60 & 0.61 & 3.8 \\
\hline
\end{tabular}

*- mean calculated based on raster cells, \pm indicates standard deviation. Mean soil loss is also referred to as internal catchment dynamics in the text. Soil export is also referred to as external catchment dynamics in the text. ${ }^{* *}$ - number of years in which catchment outlet sediment export over long-term rainfall matched that of extreme events; BLUS-steady production - baseline land use and landscape structure. I-more intensive production than B. E-less intensive production than B; $10^{-2} \mathrm{Mg} \cdot \mathrm{km}^{-2}$ equals t/ha 